\title{
Influence of Environmental Parameters on the Distribution and Diversity of Molluscan Composition in Pondicherry Mangroves, Southeast Coast of India
}

\author{
Palanisamy Satheeshkumar, ${ }^{1,2 *}$ and Anisa Basheer Khan ${ }^{2}$ \\ ${ }^{1}$ Central Marine Fisheries Research Institute, P.O.Box 1603, Kochi-682 018, Kerala, India \\ ${ }^{2}$ Department of Ecology and Environmental Sciences, Pondicherry University, Puducherry 605014, India
}

Received 3 December 2011; Revised 2 February 2012; Accepted 21 March 2012

(c) KSO, KORDI and Springer 2012

\begin{abstract}
Seasonal variation in the distribution of mollusks in relation to environmental parameters was studied at four mangrove stations on the Pondicherry coast during September 2008-August 2009. A total of 37 species of molluscs were recorded, among them 16 species of bivalves belonging to 7 families and 12 Genera, and 21 species of gastropods belonging to 14 families and 19 Genera, with the Cereithedia cingulata being the dominant group. An increase of species density and diversity in the Post monsoon season was observed, with the highest values for both indexes at stations 1 and 2, and the lowest at stations 3 and 4 fine where the sand assemblage was dominated by a few gastropods. Pollution indicator species Cassidula nucleus, Melampus ceylonicus, Sphaerassiminea minuta were found only in highly polluted regions near stations 3 and 4 ; they were totally absent in moderately polluted areas near stations 1 and 2. From a stepwise multivariate analysis of the different environmental parameters regarding molluscan density, it was found that in all 10 parameters govern the density variation of benthic mollusks in Pondicherry mangroves and that the organic matter of sediment and sulphide, DO, and salinity were the highly significant ones.
\end{abstract}

Key words - bivalve, correlation, diversity, gastropod, Pondicherry mangroves

\section{Introduction}

The naturally productive Pondicherry mangrove ecosystem is associated with different organisms in the micro and macro habitat of the mangals itself and also in the intertidal region besides the adjacent mangrove waters. Mangrove ecosystem

*Corresponding author. E-mail: indianscientsathish@gmail.com acts as a buffer zone between land and sea (Bardarudeen et al. 1996) with the intertidal soil providing a suitable habitat for a variety of benthic fauna. The evaluation and conservation of the coastal ecosystem biodiversity is imperative to sustain productivity and invertebrates have attracted attention in terms of conservation in addition to being monitored (Brendan et al. 2007).

Assessment of changes in coastal ecosystems can be effectively monitored using benthic fauna, as they play an important role in the transfer of materials from primary production through the detrital pool into higher trophic levels, including commercially exploitable fish (Ingole et al. 2006). The relation between the benthic standing stock and demersal fish resources has been very well documented for Indian waters (Jones 1997) and as the majority of the benthic fauna are sedentary and sessile, they cannot avoid any environmental perturbation (Danulat et al. 2002), and so are considered a sensitive indicator of changes in the environment caused by natural and anthropogenic disturbances.

Molluscs, a bioenergetically significant group, constitute one of the most dominant macrobenthic faunal components in all the mangrove ecosystems of the world. Molluscs have been shown to be an appropriate indicator group for local invertebrate biodiversity (Gladstone 2002). Mollusks species abundance and annual distribution patterns have been recorded in Indian mangroves by different authors (Raut et al. 2005; Saravanakumar et al. 2007). But, for a better understanding of the benthic ecosystem, studies on the relationship between mollusks and the environment along the whole stretch of the mangrove ecosystem are essential. 
In this present study, the molluscan distribution in Pondicherry mangroves in relation to different environmental parameters is given. To our knowledge, this is the first detailed study on the species composition and diversity of benthic molluscan fauna in the mangroves of Pondicherry.

\section{Materials and Methods}

\section{Study station}

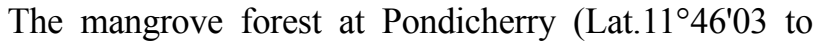
$11^{\circ} 53^{\prime} 40 \mathrm{~N}$ : Long. $79^{\circ} 49^{\prime} 45$ to $79^{\circ} 48^{\prime} 00 \mathrm{E}$ ) is located along the south-east coast of India (Fig. 1). It is one of the typical mangrove swamps of the Ariyankuppam estuarine complex, covering an area of 168 ha distributed along the sides of the Ariankuppam estuary, which is a seasonally bar-built and semi diurnal type that flows eastwards and empties into the Bay of Bengal at Veerampatinam on south east coast of India. Along its exposed banks and on its upper reaches it is fringed with mangrove trees covering an area of approximately 30ha. Four different sampling stations were chosen with $2 \mathrm{kms}$ distance between any two stations; station 1 receives neritic waters from the adjacent Bay of Bengal at the mouth of Veerampattinam; station 2, at Thengaithittu, is located interiorly and is characterized by brackish water; station 3 , at Ariyankuppam, is located $4 \mathrm{~km}$ south of Pondicherry harbor, and receives water carrying wastes from adjacent agriculture lands and industries in addition to domestic municipal and distillery effluents. Station 4, at Murungapakkam, is located interiorly and has much more dense vegetation on the banks of its waterway. The tides are semi-diurnal and vary in amplitude from 15 to $100 \mathrm{~cm}$ in different regions during different seasons, reaching a maximum during monsoon and post monsoon and a minimum during summer.

\section{Sample collection and laboratory procedures}

Triplicate samples were collected every month using a metal quadrat of $25 \mathrm{~cm} \times 25 \mathrm{~cm}$ in size up to a depth of $15 \mathrm{~cm}$ (Eleftheriou and Holme 1984) along three transects, each oriented perpendicularly to the coast line. Vanveen grab $\left(0.1 \mathrm{~m}^{2}\right)$ was also employed to collect the mangrove bottom soil samples and molluscan organisms in the sub tidal (5-10 m depth), samples were preserved in $10 \%$ formalin. The Molluscs in the sediment sample recovered after sieving through $500 \mu \mathrm{m}$ sieve was brought to the laboratory in polythene bags, transferred to a large white bottomed tray and the animals which were moving or easily recognizable were hand sorted. The surface water temperature was measured using a standard thermometer. Salinity was measured by a hand held Refractometer (ERMA), water $\mathrm{pH}$ was also measured (by a hand held $\mathrm{pH}$ meter, $\mathrm{pH}$ scan-2); electrical conductivity (EC) was measured using EC instruments. Dissolved oxygen was estimated by Winkler's method and sulphide was also determined (by Strickland and Parson's 1972 method), sediment texture (Krumbein and Pettijohn 1983) was determined by a pipette analysis method. The total organic matter of sediment was determined by the wet

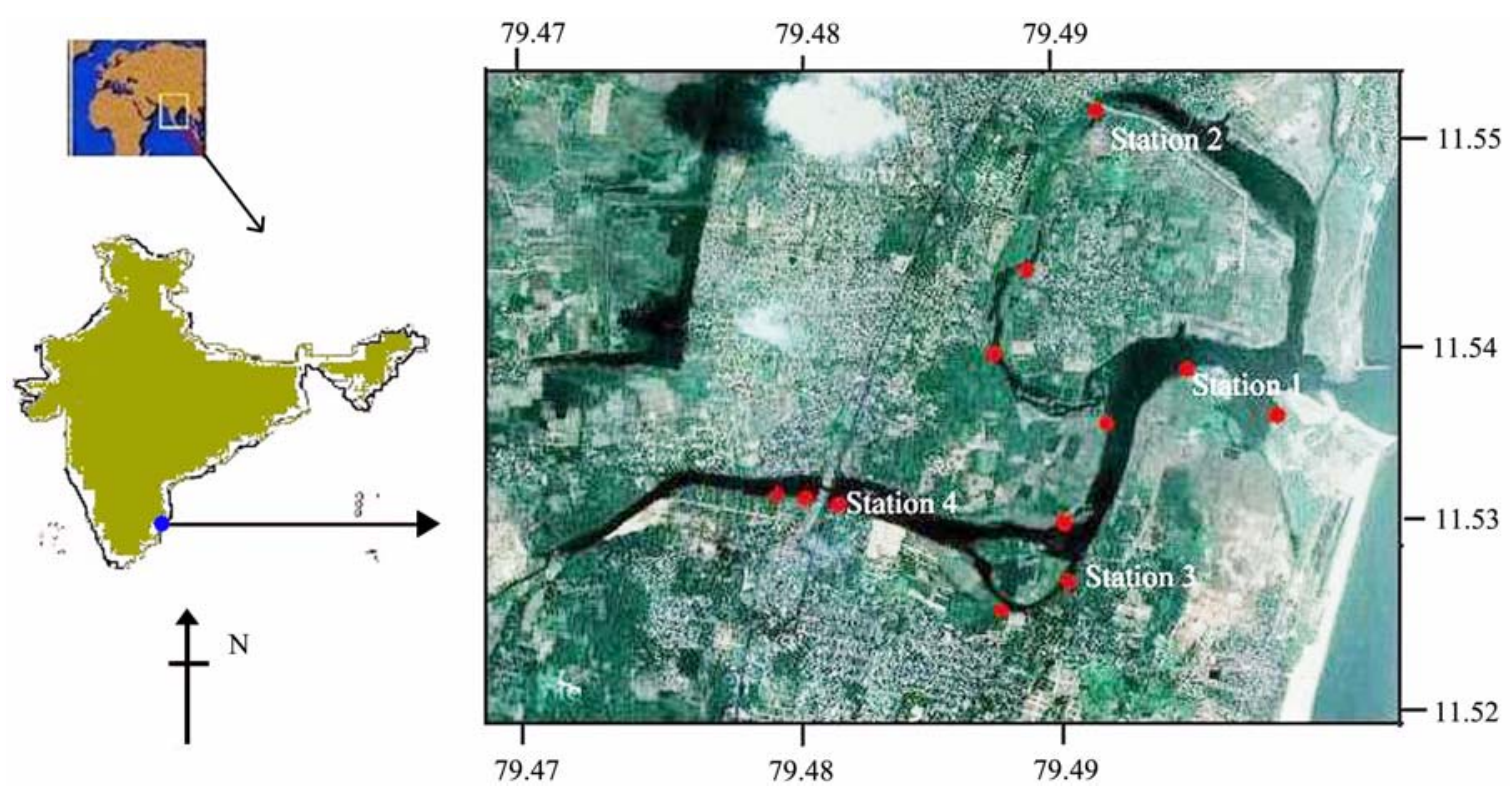

Fig. 1. Map of the study area showing station location points along the three transects are also indicated 
oxidation method (El Wakeel and Riley 1957). Fauna were identified and categorized to the lowest practical taxonomic level using standard references (Antony Fernando and Olivia Fernando 2002). The data was subjected to univariate analyses for studying the molluscan community structure using Shannon and Weaver (1949) for species diversity, Pielou (1966) for species dominance and evenness and Gleason (1992) was used to determine species richness. The Pearson correlation coefficient was used to study the affinity of benthic groups towards environmental parameters.

\section{Statistical analysis}

Statistical analyses were performed using SPSS (statistical Version 7.5 for Windows XP, SPSS, and Chicago, IL, USA). The Pearson correlation ( $r$ ) was made for the statistical interpretation of the physico-chemical parameters of water, sediment characteristics and molluscan species diversity indices. The relationship between molluscan species abundance and different environmental parameters was determined using multivariate statistical analysis such as Cluster analysis (CA) and a Multidimensional Scale plot (MDS) was constructed based on the abundance of molluscs after log transformation. Based on the obtained cluster analysis of groups, species having the greatest contribution to this division were determined using a similarity percentage program PAST (statistical Version 1.93 for Windows XP).

\section{Results and Discussion}

\section{Water quality parameters}

Mean and standard deviation on the physico-chemical parameters of water and sediment characteristics is presented (Table 1). Total annual rainfall in the study area was $1520.7 \mathrm{~mm}$, with monthly variations from $1.1-808 \mathrm{~mm}$. The relative humidity of the atmosphere varied from 37$100(\%)$ with the monsoon season (October-December) having the highest range and the summer season having the lowest range. Rainfall brings important changes in the estuarine hydrographical characteristics (Rajkumar et al. 2009).

Surface water temperatures in the study area varied from $16.66{ }^{\circ} \mathrm{C}-37.91{ }^{\circ} \mathrm{C}$ respectively, with the maximum during summer and minimum during monsoon. There was no relationship between the air and surface water temperatures, which could be due to different environmental situations (Ashok Prabu et al. (2008). Salinity indicated wide variations ranging between 6.36-36.77; indicating an influx of freshwater from land run off, caused by monsoon or by tidal

Table 1. Seasonal variation of Physico-chemical parameters of water and sediment characteristics

\begin{tabular}{|c|c|c|c|c|c|c|c|c|c|c|}
\hline Season & Salinity & $\mathrm{T}^{\circ} \mathrm{C}$ & $\mathrm{pH}$ & DO & $\mathrm{EC}$ & Sulphide & Sand (\%) & Silt (\%) & Clay (\%) & OM (\%) \\
\hline \multicolumn{11}{|l|}{ Monsoon } \\
\hline Station 1 & $14.31 \pm 6.91$ & $22.89 \pm 4.52$ & $7.28 \pm 0.07$ & $5.16 \pm 0.22$ & $33.20 \pm 3.98$ & $5.01 \pm 1.65$ & $85.38 \pm 3.64$ & $10.45 \pm 7.81$ & $4.17 \pm 1.59$ & $0.94 \pm 0.31$ \\
\hline Station 2 & $12.49 \pm 2.61$ & $21.66 \pm 4.33$ & $7.34 \pm 0.26$ & $4.72 \pm 0.57$ & $30.60 \pm 3.44$ & $5.26 \pm 0.17$ & $69.92 \pm 11.18$ & $23.61 \pm 6.48$ & $6.47 \pm 4.98$ & $1.94 \pm 0.89$ \\
\hline Station 3 & $15.67 \pm 3.92$ & $22.56 \pm 4.82$ & $7.26 \pm 0.17$ & $4.85 \pm 0.61$ & $36.48 \pm 4.53$ & $13.75 \pm 11.65$ & $73.24 \pm 17.20$ & $21.60 \pm 12.94$ & $5.81 \pm 3.18$ & $3.21 \pm 0.88$ \\
\hline Station 4 & $17.13 \pm 2.08$ & $21.66 \pm 4.57$ & $7.33 \pm 0.12$ & $4.49 \pm 0.07$ & $35.85 \pm 4.30$ & $20.39 \pm 19.07$ & $75.78 \pm 4.02$ & $22.53 \pm 2.85$ & $3.49 \pm 0.44$ & $3.3 \pm 0.79$ \\
\hline \multicolumn{11}{|c|}{ Postmonsoon } \\
\hline Station 1 & $25.77 \pm 4.33$ & $25.59 \pm 0.94$ & $8.02 \pm 0.43$ & $5.01 \pm 0.41$ & $41.33 \pm 4.26$ & $5.89 \pm 1.50$ & $72.40 \pm 16.31$ & $16.66 \pm 14.41$ & $10.01 \pm 0.84$ & $1.58 \pm 0.31$ \\
\hline Station 2 & $26.55 \pm 3.16$ & $23.48 \pm 0.73$ & $7.73 \pm 0.35$ & $4.47 \pm 0.34$ & $39.61 \pm 6.74$ & $7.88 \pm 1.98$ & $74.55 \pm 21.19$ & $17.39 \pm 20.67$ & $8.22 \pm 4.47$ & $2.07 \pm 1.27$ \\
\hline Station 3 & $21.78 \pm 0.59$ & $.39 \pm 0.89$ & $7.44 \pm 0.21$ & $4.09 \pm 0.05$ & $39.19 \pm 6.73$ & $17.64 \pm 4.26$ & $67.60 \pm 22.37$ & $26.06 \pm 24.07$ & $6.23 \pm 1.91$ & $3.13 \pm 0.86$ \\
\hline Station 4 & $16.56 \pm 2.83$ & $22.23 \pm 1.10$ & $7.46 \pm 0.09$ & $3.71 \pm 0.27$ & $32.79 \pm 7.07$ & $25.26 \pm 3.89$ & $39.54 \pm 22.62$ & $29.35 \pm 8.03$ & $31.20 \pm 22.35$ & $3.53 \pm 0.71$ \\
\hline \multicolumn{11}{|c|}{ Summer } \\
\hline Station 1 & $35.28 \pm 2.34$ & $35.85 \pm 2.42$ & $8.30 \pm 0.09$ & $4.20 \pm 0.27$ & $34.88 \pm 9.07$ & $4.19 \pm 1.28$ & $87.31 \pm 9.74$ & $9.89 \pm 11.46$ & $3.06 \pm 1.59$ & $1.74 \pm 0.51$ \\
\hline Station 2 & $33.66 \pm 1.20$ & $35.68 \pm 3.02$ & $7.92 \pm 0.16$ & $4.41 \pm 0.70$ & $37.28 \pm 10.8$ & $10.42 \pm 1.89$ & $83.42 \pm 11.46$ & $12.23 \pm 9.36$ & $4.99 \pm 3.021$ & $2.18 \pm 0.39$ \\
\hline Station 3 & $28.68 \pm 1.51$ & $32.31 \pm 4.30$ & $7.60 \pm 0.35$ & $3.94 \pm 0.25$ & $39.44 \pm 11.19$ & $13.80 \pm 0.22$ & $75 \pm 11.48$ & $15.31 \pm 8.64$ & $10.49 \pm 10.23$ & $3.64 \pm 0.45$ \\
\hline Station 4 & $27.37 \pm 3.33$ & $31.71 \pm 5.02$ & $7.41 \pm 0.27$ & $3.87 \pm 0.56$ & $39.75 \pm 10.9$ & $20.67 \pm 1.55$ & $67.88 \pm 29.44$ & $14.72 \pm 19.25$ & $17.98 \pm 11.24$ & $3.76 \pm 0.44$ \\
\hline \multicolumn{11}{|c|}{ Premonsoon } \\
\hline Station 1 & $29.98 \pm 1.34$ & $29.55 \pm 1.85$ & $7.80 \pm 0.23$ & $4.63 \pm 0.095$ & $39.59 \pm 5.40$ & $5.65 \pm 0.54$ & $71.83 \pm 21.02$ & $24.21 \pm 20.75$ & $4.04 \pm 0.42$ & $1.12 \pm 0.30$ \\
\hline Station 2 & $27.89 \pm 3.15$ & $28.63 \pm 5.12$ & $7.66 \pm 0.13$ & $4.31 \pm 0.21$ & $39.22 \pm 7.02$ & $8.40 \pm 1.32$ & $63.69 \pm 22.63$ & $25.66 \pm 9.06$ & $11.76 \pm 12.51$ & $1.20 \pm 0.36$ \\
\hline Station 3 & $27.85 \pm 2.64$ & $28.45 \pm 2.59$ & $7.55 \pm 0.12$ & $4.28 \pm 0.24$ & $36.51 \pm 8.54$ & $26.25 \pm 6.88$ & $77.87 \pm 10.06$ & $18.02 \pm 8.69$ & $4.07 \pm 2.05$ & $3.82 \pm 0.74$ \\
\hline Station 4 & $27.27 \pm 1.75$ & $27.56 \pm 4.57$ & $7.48 \pm 0.24$ & $4.01 \pm 0.15$ & $37.35 \pm 10.23$ & $40.43 \pm 10.57$ & $68.13 \pm 12.28$ & $26.41 \pm 12.84$ & $5.54 \pm 0.74$ & $3.94 \pm 0.68$ \\
\hline
\end{tabular}

$\mathrm{T}^{\circ} \mathrm{C}=$ Temperature; $\mathrm{DO}=$ Dissolved Oxygen; $\mathrm{EC}=$ Electrical Conductivity; $\mathrm{OM}=$ Organic matter 
variations, and is evidenced by a negative correlation $(r=-0.65$ at station $1, r=-0.69$ at station 2 and $r=-0.869$ at station 3 $\mathrm{r}=-0.7654$ at station 4) obtained between salinity and rainfall. The salinity is a limiting factor in the distribution of living organisms, as dilution and evaporation impact most likely on the fauna in the coastal ecosystem (Balasubramanian and Kannan 2005). Dissolved oxygen was high (5.49 mg/l) during monsoon and low $(3.45 \mathrm{mg} / \mathrm{l})$ during summer and season-wise observation of dissolved oxygen indicated an inverse trend with temperature and salinity. The high values observed during monsoon are certainly due to the cumulative effect of higher wind velocity, a heavy rainfall, and freshwater inflow and to the terrigenous impact of sediments (Rajaram et al. 2005).

Hydrogen ion concentration $(\mathrm{pH})$ varied from 7.11 to $8.52, \mathrm{pH}$ in surface waters remained slightly alkaline throughout the study period at all 4 stations with the maximum during summer and minimum during monsoon. The high $\mathrm{pH}$ values recorded during summer might be due to the influence of seawater penetration and high biological activity (Rajkumar et al. 2009). EC at the four stations varied from $26.65-52 \mathrm{~ms}^{-1}$ with maximum EC $\left(52 \mathrm{~ms}^{-1}\right)$ recorded at station 3. Seasonal mean fluctuations recorded in sulphide concentration varied from $2.76-47.16 \mathrm{mg} / \mathrm{l}$ respectively with the maximum content of sulphide $(47.16 \mathrm{mg} / \mathrm{l})$ recorded at station 4 . Significant negative correlation between sulphide and DO $(r=-0.601$; $\mathrm{P}<0.05$ ) at station 4 indicates that DO is largely influenced by sulphide at this station.

\section{Mangrove sediment characteristics}

At all the areas, the substratum was predominated by sand followed by silt and clay in comparatively smaller proportions. Sand fraction ranged between $63.69-87.31 \%$ followed by silt (9.89-29.32\%), clay (3.06-17.98\%). The highest value for sand was observed in summer and monsoon seasons $(83-87 \%)$ and slightly less in post-monsoon (39\%). Silt percentage remained almost the same during all seasons, showing little variation, but a comparatively higher percentage of clay was observed in post-monsoon season. Soil texture sand, silt and clay indicated a highy significant correlation at $\mathrm{P}<0.01$. Organic matter varied (from $0.94-3.94 \%$ ), which is attributed to the transport of sediments from one place to another associated with tidal currents and was relatively high in the pre monsoon season. There were significant negative correlations between $\mathrm{OM}$ and clay $(\mathrm{r}=-0.537$; $\mathrm{P}<0.05)$ and sulphide $(\mathrm{r}=-0.60 ; \mathrm{P}<0.05)$ at stations 3 and 4 .

\section{Molluscan abundance and diversity}

In total 37 species were recorded from all the four stations (Table 2) with gastropods forming the dominant group. 21 species of gastropod species belonging to 14 families and

Table 2. Check List of Benthic fauna recorded at Stations 1-4, Pondicherry mangroves

\begin{tabular}{|c|c|c|c|c|c|}
\hline \multirow{2}{*}{ No } & \multirow{2}{*}{ Species } & \multirow{2}{*}{$\begin{array}{c}\text { Station } \\
1 \\
\end{array}$} & \multicolumn{3}{|c|}{ Station Station Station } \\
\hline & & & 2 & 3 & 4 \\
\hline & Mollusca & & & & \\
\hline & Bivalvia & & & & \\
\hline 1 & Anadara granosa & + & + & + & + \\
\hline 2 & A. rhombea & + & + & + & - \\
\hline 3 & Bivalve spat & - & - & + & - \\
\hline 4 & Crassostrea madrasensis & + & + & + & + \\
\hline 5 & Cucullea cucullata & + & - & - & - \\
\hline 6 & Donax faba & + & - & - & - \\
\hline 7 & D. scortum & + & - & - & - \\
\hline 8 & Mactra laevis & - & + & - & - \\
\hline 9 & Marcia opima & + & - & - & - \\
\hline 10 & Meretrix meretrix & + & + & + & + \\
\hline 11 & M. casta & + & + & + & + \\
\hline 12 & Perna viridis & + & + & + & - \\
\hline 13 & P. indica & + & - & - & - \\
\hline 14 & Scapharca inaequivalvis & + & - & - & - \\
\hline 15 & Saccostrea cucullata & + & - & + & - \\
\hline 16 & $\begin{array}{l}\text { Modiolus metcalfei } \\
\text { Gastropoda }\end{array}$ & + & - & - & - \\
\hline 17 & Cantharus tranquebaricus & + & + & - & - \\
\hline 18 & Cassidula nucleus & - & - & + & + \\
\hline 19 & Cerithidea cingulata & + & + & + & + \\
\hline 20 & C. obtusa & - & + & - & - \\
\hline 21 & Clithon oualaniensis & + & + & - & - \\
\hline 22 & Herpetopoma sp & + & - & - & - \\
\hline 23 & Melampus ceylonicus & - & - & + & + \\
\hline 24 & Littorina melanostoma & - & - & + & - \\
\hline 25 & Natica marochiensis & + & + & + & + \\
\hline 26 & Nassarius pullus & - & - & - & + \\
\hline 27 & N. stolatus & + & + & + & - \\
\hline 28 & Neritina violacea & - & - & + & + \\
\hline 29 & Polinices mammilla & + & + & - & - \\
\hline 30 & Sinum neritoideum & + & - & - & - \\
\hline 31 & Sphaerassiminea minuta & - & - & + & + \\
\hline 32 & Telescopium telescopium & + & + & + & + \\
\hline 33 & Thais bufo & - & + & - & - \\
\hline 34 & Trochus radiatus & + & - & - & - \\
\hline 35 & Turbo brunneus & + & - & - & - \\
\hline 36 & Turritella attenuata & + & - & - & - \\
\hline 37 & Vittina coromandeliana & + & + & + & - \\
\hline
\end{tabular}

(+) Presence; (-) absence 


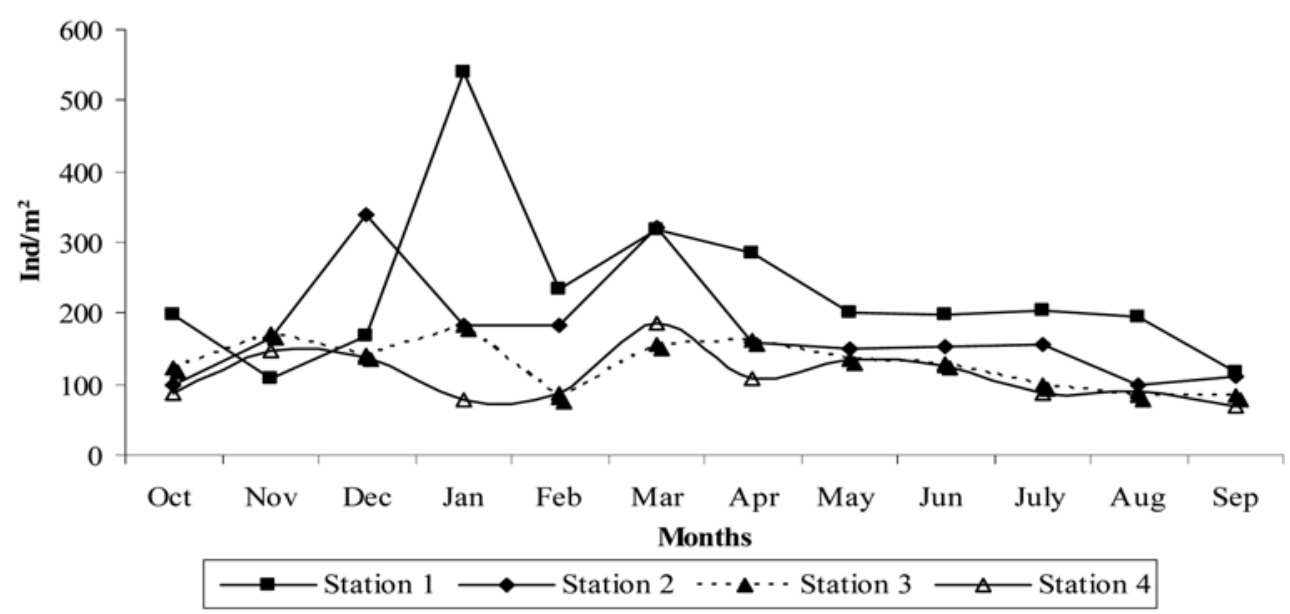

Fig. 2. Monthly variations in molluscan species density at stations 1-4 of Pondicherry mangroves

19 genera and a total of 16 species of bivalves belonging to 7 families under 10 genera were recorded throughout the year. The density of bivalves and gastropods ranged between 68-541 ind. $\mathrm{m}^{-2}$ with a maximum density in post monsoon and a minimum in monsoon (Fig. 2). Gastropods ranged between 36-333 ind. $\mathrm{m}^{-2}$ and among the gastropods Cerithedia cingulata was the most dominant followed by Cassidula nucleus, Melampus ceylonicus, Sphaerassiminea minuta and Telescopium telescopium. Gastropods play a vital role at the debris interface as they consume living and decaying plant material (Brendan et al. 2007). The range of bivalves was between 12-20 ind. $\mathrm{m}^{-2}$ and among the bivalves Crassostrea madrasensis was the most dominant followed by Meretrix meritrix, M. casta, Perna viridis and Anadara granosa. Molluscan abundance ranged between 68-541 ind.m ${ }^{-2}$, diversity ranged between $0.65-1.497$ bits ind $^{-1}$, richness ranged between 0.39-0.75, evenness ranged between $0.56-0.72$, equitability ranged between $0.35-0.84$, and fisher alpha ranged between 1.47-3.28 (Table 3).

Molluscs in mangrove beds form an important component

Table 3. Seasonal variation of diversity indices at stations 1-4 of Pondicherry mangroves

\begin{tabular}{|c|c|c|c|c|c|c|}
\hline Season & Dominance & "S. Wiener Diversity (H) & Evenness (J) & "Richness (D) & Equitability (J) & Fisher Alpha \\
\hline \multicolumn{7}{|l|}{ Premonsoon } \\
\hline Station 1 & $0.506 \pm 0.015$ & $1.300 \pm 0.180$ & $0.271 \pm 0.041$ & $0.499 \pm 0.024$ & $0.499 \pm 0.0325$ & $3.489 \pm 0.374$ \\
\hline Station 2 & $0.586 \pm 0.0386$ & $1.225 \pm 0.009$ & $0.272 \pm 0.037$ & $0.412 \pm 0.037$ & $0.543 \pm 0.181$ & $2.656 \pm 0.044$ \\
\hline Station 3 & $0.374 \pm 0.052$ & $1.048 \pm 0.821$ & $0.737 \pm 0.030$ & $0.757 \pm 0.041$ & $0.841 \pm 0.003$ & $1.753 \pm 0.413$ \\
\hline Station 4 & $0.336 \pm 0.064$ & $1.206 \pm 0.064$ & $0.657 \pm 0.071$ & $0.696 \pm 0.028$ & $0.753 \pm 0.0621$ & $1.387 \pm 0.180$ \\
\hline \multicolumn{7}{|l|}{ Monsoon } \\
\hline Station 1 & $0.653 \pm 0.046$ & $1.185 \pm 0.11$ & $0.216 \pm 0.008$ & $0.327 \pm 0.030$ & $0.357 \pm 0.025$ & $2.967 \pm 0.351$ \\
\hline Station 2 & $0.745 \pm 0.050$ & $1.125 \pm 0.25$ & $0.207 \pm 0.045$ & $0.253 \pm 0.50$ & $0.293 \pm 0.05$ & $2.173 \pm 0.179$ \\
\hline Station 3 & $0.412 \pm 0.056$ & $0.878 \pm 0.077$ & $0.467 \pm 0.088$ & $0.653 \pm 0.086$ & $0.652 \pm 0.085$ & $2.524 \pm 0.455$ \\
\hline Station 4 & $0.481 \pm 0.039$ & $0.654 \pm 0.087$ & $0.428 \pm 0.068$ & $0.584 \pm 0.106$ & $0.602 \pm 0.081$ & $2.298 \pm 0.562$ \\
\hline \multicolumn{7}{|l|}{ Postmonsoon } \\
\hline Station 1 & $0.435 \pm 0.045$ & $1.497 \pm .0 .071$ & $0.300 \pm 0.36$ & $0.565 \pm 0.043$ & $0.553 \pm 0.037$ & $3.217 \pm 0.252$ \\
\hline Station 2 & $0.471 \pm 0.092$ & $1.361 \pm 0.241$ & $0.314 \pm 0.036$ & $0.527 \pm 0.09$ & $0.535 \pm 0.068$ & $2.954 \pm 0.677$ \\
\hline Station 3 & $0.316 \pm 0.02$ & $0.719 \pm 0.056$ & $0.591 \pm 0.166$ & $0.682 \pm 0.024$ & $0.730 \pm 0.102$ & $1.757 \pm 0.600$ \\
\hline Station 4 & $0.305 \pm .0 .02$ & $0.682 \pm 0.034$ & $0.631 \pm 0.05$ & $0.696 \pm 0.025$ & $0.750 \pm 0.039$ & $1.47 \pm 0.035$ \\
\hline \multicolumn{7}{|l|}{ Summer } \\
\hline Station 1 & $0.578 \pm 0.058$ & $1.315 \pm 0.089$ & $0.435 \pm 0.101$ & $0.391 \pm 0.049$ & $0.400 \pm 0.028$ & $3.281 \pm 0.618$ \\
\hline Station 2 & $0.539 \pm 0.160$ & $1.258 \pm 0.121$ & $0.340 \pm 0.042$ & $0.401 \pm 0.054$ & $0.474 \pm 0.0102$ & $2.763 \pm 0.192$ \\
\hline Station 3 & $0.397 \pm 0.071$ & $1.021 \pm 0.052$ & $0.453 \pm 0.062$ & $0.609 \pm 0.155$ & $0.614 \pm 0.006$ & $2.802 \pm 0.091$ \\
\hline Station 4 & $0.337 \pm 0.017$ & $1.136 \pm 0.065$ & $0.58 \pm 0.181$ & $0.601 \pm 0.102$ & $0.730 \pm 0.0621$ & $1.569 \pm 0.549$ \\
\hline
\end{tabular}


of the fauna, based on their species richness and number of individuals (Saravanakumar et al. 2007). C. madrasensis formed large beds at station 1 and 2 but occurreed in patches at station 3. T. telescopium, M. meritrix, M. casta, C. cingulata and $P$. viridis were observed throughout the study period at both stations 1 and 2. Pollution indicator species such as $C$. nucleus, Neritia violacea, M. ceylonicus, S. minuta were recorded at stations 3 and 4. Modiolus metcalfei, Cerithidea obtusa, Cantharus tranqubaricus are found more during post monsoon at the mud and sand flats near the mouth of the estuary (station 1). Abundance and diversity in the present study was comparable with that of Kathiresan (2000) who studied the molluscan distribution in the southeast cost of India. In contrast among the molluscan assemblage from the mangroves of Godavari and Krishna estuarine systems (Raut et al. 2005), only 95 species belonging to 11 genera were noticed. Saravanakumar et al. (2007) recorded 17 species of gastropods and 16 species of bivalves in the Arid Zone Mangroves of Gulf of Kachch. Saravanan et al. 2008 had recorded 9 species of gastropods and 4 species of bivalves in an earlier study in the same mangrove. In this present study in Pondicherry mangroves 16 bivalves and 21 gastropods were recorded which indicates an increase of molluscan abundance in the area. High abundance of molluscs was correlated with an increase in dissolved oxygen, salinity, $\mathrm{pH}$ and decomposed organic matter (Bath et al. 1999). The richness of molluscs presently observed may be attributed to the cumulative effect of the alkaline nature of water, high organic matter and water sulphide which provide both food and shelter, because some of these forms are periphytic in nature.

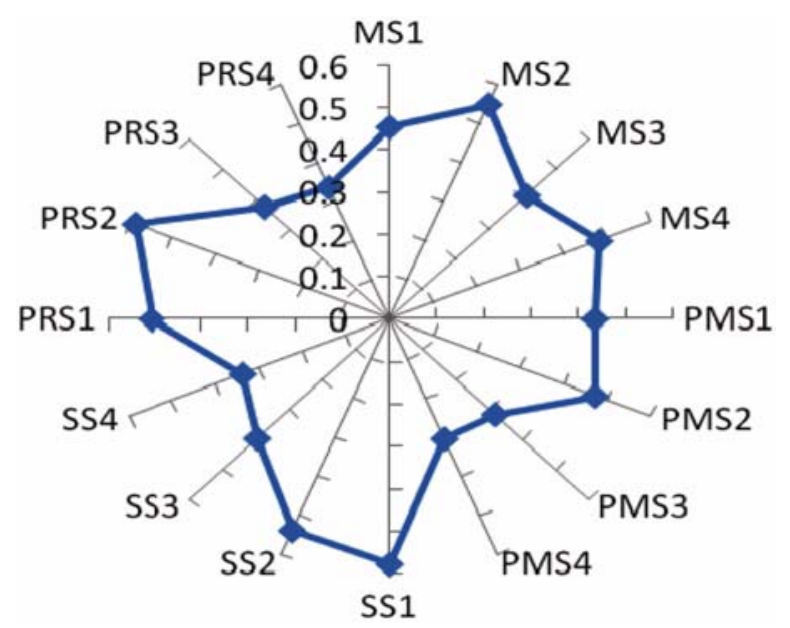

Fig. 3. Species Dominance at stations 1-4 of Pondicherry mangroves

The molluscan fauna in the study area showed great diversity in stations 1 and 2 and less diversity in stations 3 and 4. Species dominance was least $(0.30)$ at station 4 and most dominant (0.74) at station 2 (Fig. 3). Values of $\mathrm{H}^{\prime}$ varied from $0.65-1.49$, the highest $H^{\prime}$ value was observed in post monsoon season at station 1 and least observed in station $4(0.65)$. Evenness was least $(0.20)$ at station 2 during monsoon and highest (0.73) at station 3 in pre monsoon. Species richness index values varied from 0.25 to 0.75 , based on average diversity indices computed for each station, it was noticed that there was a steady decrease in the species richness index from station 1 to 4 (Fig. 4). Equitability was least at station $2(0.293)$ in monsoon and the greatest was observed in post monsoon at station 3. Fisher alpha varied from 1.47-3.48, the highest value was observed in

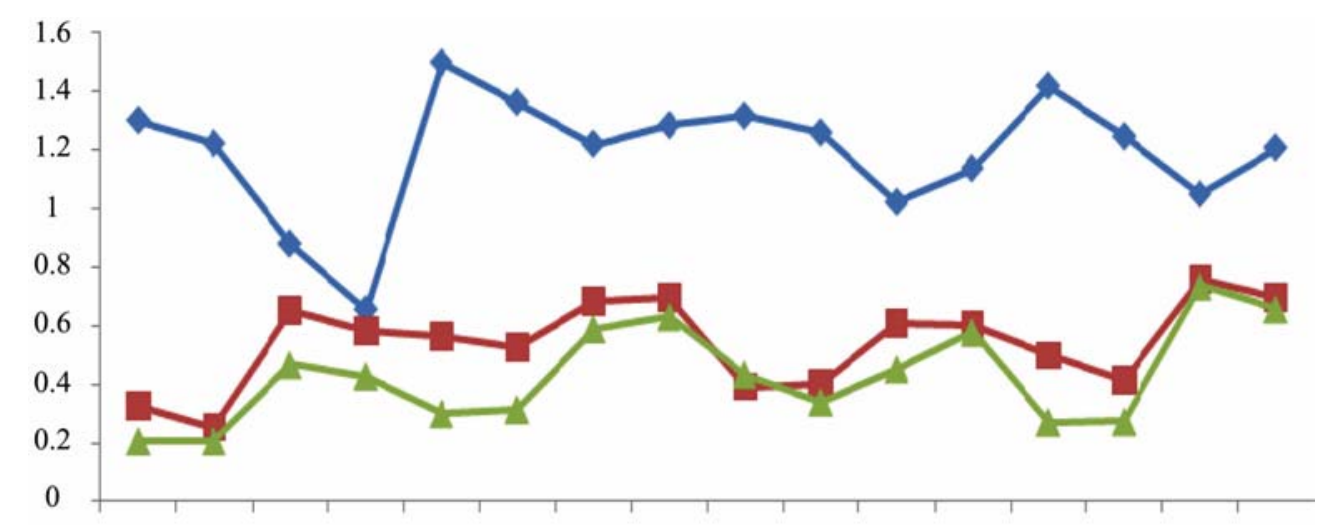

MS1 MS2 MS3 MS4 PMS1PMS2PMS3PMS4 SS1 SS2 SS3 SS4 PRS1 PRS2 PRS3 PRS4

$\multimap$ Sha. Diversity (H) $\quad \longrightarrow$ Richness (D) $\quad \longrightarrow$ Evenness

Fig. 4. Species Diversity indices at stations 1-4 of Pondicherry mangroves 


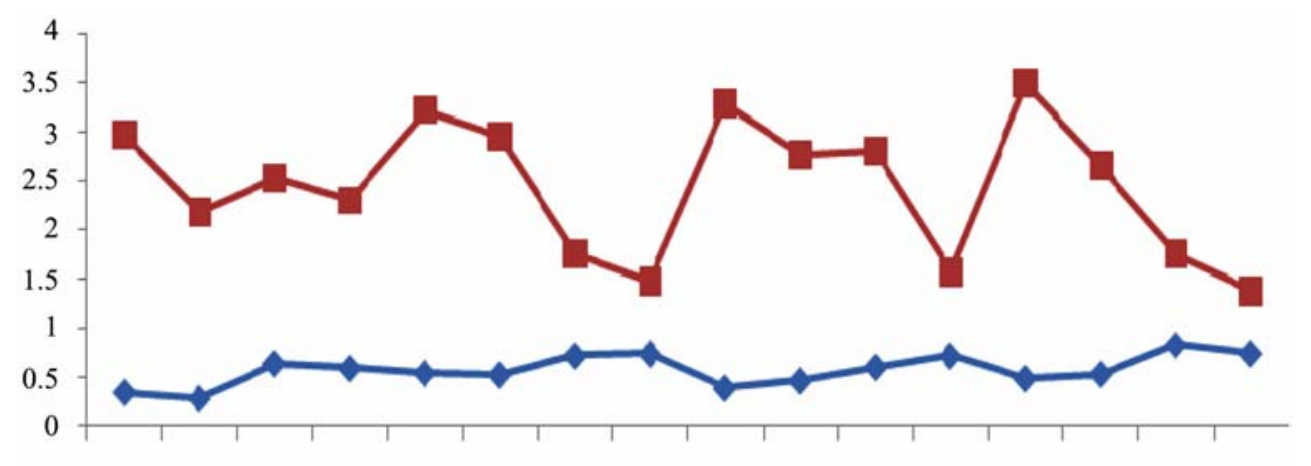

MS1 MS2 MS3 MS4 PMS1PMS2PMS3PMS4 SS1 SS2 SS3 354 PRS1 PRS2 PRS3 PRS4

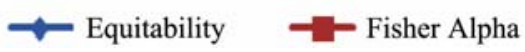

Fig. 5. Equitability and Fisher alpha at stations 1-4 of Pondicherry mangroves

pre monsoon at station 1 and least at station 4 (1.47) in post monsoon season (Fig. 5).

Diversity and density of the macro benthos is largely dependent on chance settlement of pelagic larval forms of different species, affinity to suitable substratum and also the degree of stress caused by strong waves and tide currents (Olive et al. 2002). Field et al. (1982) postulated that species diversity is mainly controlled by fluctuations in the environment and in the present study species diversity ranged between 0.65-1.497 in 4 stations over four seasons, evidencing the dynamic nature of the mangrove habitat under investigation. The pattern of low species diversity in monsoon and high diversity in post monsoon recorded at the study stations is in conformity with earlier observations (Raut et al. 2005; Garg et al. 2009).

Wilhm \& Dorris (1966) stated that values $<1.0$ for diversity index $(H)$ in estuarine waters was common when heavy pollution occurred; values between 1.0 and 3.0 indicated moderate pollution; and values exceeding 3.0 characterized non-polluted waters. Diversity value in the study area ranged between $0.65-1.497$. Thus clearly indicating that the mangroves are polluted and molluscan community is under stress due to natural and/ or anthropogenic factors.

Table 4. Correlation of species diversity indices with environmental parameters

\begin{tabular}{|c|c|c|c|c|c|c|c|c|c|c|c|c|c|c|c|c|c|}
\hline & $\begin{array}{l}\text { Domi- } \\
\text { nance }\end{array}$ & Sha & $\begin{array}{l}\text { Rich- } \\
\text { ness }\end{array}$ & Even & Marg & Equita & $\begin{array}{l}\text { Fisher } \\
\text { Alpha }\end{array}$ & $\begin{array}{l}\text { Sali- } \\
\text { nity }\end{array}$ & $\mathrm{pH}$ & $\mathrm{T}$ & DO & $\mathrm{EC}$ & $\begin{array}{c}\text { Sul- } \\
\text { phide }\end{array}$ & Sand & Silt & Clay & $\mathrm{OM}$ \\
\hline Dominance & 1.000 & & & & & & & & & & & & & & & & \\
\hline Sha & -0.854 & 1.000 & & & & & & & & & & & & & & & \\
\hline Richness & -0.949 & 0.876 & 1.000 & & & & & & & & & & & & & & \\
\hline Evenness & -0.858 & 0.657 & 0.888 & 1.000 & & & & & & & & & & & & & \\
\hline Marg & 0.562 & -0.204 & -0.577 & -0.700 & 1.000 & & & & & & & & & & & & \\
\hline Equita & -0.929 & 0.793 & 0.959 & 0.935 & -0.655 & 1.000 & & & & & & & & & & & \\
\hline Fisher Alpha & 0.551 & -0.166 & -0.559 & -0.801 & 0.919 & -0.690 & 1.000 & & & & & & & & & & \\
\hline Salinity & -0.154 & 0.318 & 0.050 & 0.063 & 0.415 & 0.092 & 0.303 & 1.000 & & & & & & & & & \\
\hline $\mathrm{pH}$ & 0.142 & 0.096 & -0.235 & -0.289 & 0.605 & -0.281 & 0.594 & 0.790 & 1.000 & & & & & & & & \\
\hline $\mathrm{T}$ & -0.003 & 0.121 & -0.125 & 0.010 & 0.437 & -0.049 & 0.264 & 0.890 & 0.672 & 1.00 & & & & & & & \\
\hline DO & 0.610 & -0.330 & -0.497 & -0.682 & 0.421 & -0.601 & 0.599 & -0.346 & -0.021 & -0.348 & 1.000 & & & & & & \\
\hline $\mathrm{EC}$ & -0.457 & 0.608 & 0.367 & 0.094 & 0.128 & 0.355 & 0.227 & 0.587 & 0.334 & 0.335 & -0.111 & 1.000 & & & & & \\
\hline Sulphide & -0.715 & 0.443 & 0.758 & 0.883 & -0.810 & 0.817 & -0.839 & -0.036 & -0.407 & -0.093 & -0.601 & -0.002 & 1.000 & & & & \\
\hline Sand & 0.448 & -0.125 & -0.394 & -0.379 & 0.616 & -0.451 & 0.554 & 0.348 & 0.337 & 0.409 & 0.479 & 0.089 & -0.404 & 1.000 & & & \\
\hline Silt & -0.289 & 0.035 & 0.360 & 0.302 & -0.616 & 0.380 & -0.493 & -0.408 & -0.448 & -0.557 & -0.247 & -0.089 & 0.433 & -0.781 & 1.000 & & \\
\hline Clay & -0.428 & 0.153 & 0.290 & 0.320 & -0.409 & 0.366 & -0.429 & -0.177 & -0.151 & -0.135 & -0.537 & -0.060 & 0.254 & -0.856 & 0.348 & 1.000 & \\
\hline $\mathrm{OM}$ & -0.766 & 0.579 & 0.784 & 0.912 & -0.725 & 0.815 & -0.798 & -0.023 & -0.388 & 0.011 & -0.670 & 0.034 & 0.851 & -0.284 & 0.226 & 0.251 & 1.000 \\
\hline
\end{tabular}

Sha: Shanon Diversity; Even: Evenness; Marg: Margalef Diversity; Equita: Equitability; OM: Organic matter 


\section{Correlation of species diversity indices with environmental parameters}

The results of coefficient of correlation (r) indicate that there is a moderate positive correlation between the diversity indices and physico-chemical parameters (Table 4 ) of water $\mathrm{DO}$ and dominance $(\mathrm{r}=0.610 ; \mathrm{P}<0.05)$, fisher alpha $(\mathrm{r}=$ $0.599 ; \mathrm{P}<0.05) ; \mathrm{pH}$ and fisher alpha $(\mathrm{r}=0.594 ; \mathrm{P}<0.05)$, sulphide and equitability $(\mathrm{r}=0.817 ; \mathrm{P}<0.01)$, evenness $(\mathrm{r}=$ 0.883 ; $\mathrm{P}<0.01)$, richness $(\mathrm{r}=0.758 ; \mathrm{P}<0.01)$; sand and fisher alpha $(\mathrm{r}=0.554 ; \mathrm{P}<0.05) ; \mathrm{OM}$ and Equitability $(\mathrm{r}=0.815 ; \mathrm{P}<0.01)$, Evenness $(\mathrm{r}=0.890 ; \mathrm{P}<0.01)$, richness $(\mathrm{r}=0.784 ; \mathrm{P}<0.01)$. A moderate negative correlation exists between $\mathrm{DO}$ and equitability $(\mathrm{r}=-0.601 ; \mathrm{P}<0.05)$, evenness $(\mathrm{r}=-0.682 ; \mathrm{P}<0.01)$; sulphide and dominance $(\mathrm{r}=-0.755$; $\mathrm{P}<0.01)$, fisher alpha $(\mathrm{r}=-0.839 ; \mathrm{P}<0.01), \mathrm{OM}$ and dominance $(\mathrm{r}=-0.766 ; \mathrm{P}<0.01)$, fisher alpha $(\mathrm{r}=-0.798 ; \mathrm{P}<0.01)$, shannon diversity $(\mathrm{r}=-0.579 ; \mathrm{P}<0.05)$ with physico-chemical parameters of water and sediment characteristics of Pondicherry mangroves. This analysis shows that single factor effects alone could not predict the spatial variability in the distribution of molluscs and from the results it is evident that a minimum of two environmental factors influence significantly.

There was a slight reduction of DO at stations 3 and 4 and depletion of oxygen in the shelf and may be associated with the oxygen minimum layer in the shelf edge (Qasim 1982). From the results it could be inferred that both temperature and DO influenced the distribution and abundance of mollusc. The high salinity observed at the mouth of the estuary at stations 1 and 2 in the present study and low salinity at stations 3 and 4 could be due to freshwater inflow. With the optimum salinity for growth being 5-20 ppt (Ellison 2008), this could be the reason for low densities at station 3 and 4. However, several faunal species such as microorganisms, benthic invertebrates and larval forms which exclusively depend on the mangrove wetlands for their survival are highly sensitive to even a slight change in the salinity of their ecosystem (Sandilyan et al. 2010). Salinity in combination with the organic matter and median grain size of sediment was responsible for the variation in density of Meritrix meritrix and M. casta. That salinity is an influencing factor for the distribution of benthic fauna has been suggested by Sanders et al. 1965; Parulekar 1980).

Sediment characteristics have been positively related to the abundance of mollusks; however, not to any significant extent. Organic matter and sulphide indicate that there was a moderate negative correlation between the Shanon weaver diversity, fisher alpha, as well as dominance (sulphide and dominance $(\mathrm{r}=-0.755 ; \mathrm{P}<0.01)$; fisher alpha $(\mathrm{r}=-0.839$; $\mathrm{P}<0.01)$; $\mathrm{OM}$ and dominance $(\mathrm{r}=-0.766$; $\mathrm{P}<0.01)$; fisher alpha $(\mathrm{r}=-0.798 ; \mathrm{P}<0.01)$; shannon diversity $(\mathrm{r}=-0.579 ; \mathrm{P}<0.05)$. A moderate negative correlation exists between the following; molluscan diversity indices; evenness, richness and equitability with organic matter and sulphide. The high sedimentation rates at stations 3 and 4 probably could be a reason for the overall low species in the sub tidal, in particular the low species richness and density of bivalves and gastropod. Organic matter was responsible for most of the density fluctuations of molluscan species; most of them feed on suspension. For desposit feeders, the amount of organic deposit in the sediment is very important and the efficiency of their survival, reproduction and distribution mainly depends on the nutritional status of the bottom deposit in the habitat (Fenchel 1970). However, three pollution indicator gastropod species - Cassidula nucleus, Melampus ceylonicus and Sphaerassiminea minuta - are well adapted to the situation at station 4, and similar results (Nordhaus et al. 2009) have been recorded showing benthic communities affected by anthropogenic inputs in the Segara Anakan mangroves, Indonesia. Macrobenthic communities in marine environments are influenced by the texture of the sediment in which they establish themselves and live (Manjappa et al. 2003) but Ellingsen (2002) reports that biotic factors such as availability and abundance of benthic larvae/adult might be more important than sediment characteristics in determining mollusc settlement.

\section{Multivariate analyses}

Cluster analysis delineated two major clusters, which were mainly segregated based on benthos abundance and diversity indices towards environmental parameters (Fig. 6). Clusters at stations 1 and 2 were more densely populated than stations 3 and 4 . Cluster 1 consisted of increased diversity, richness and abundance of organisms observed at stations 1 and 2 and this could be due to the increase proportion of coarser sediment with a high amount of DO observed at these stations. Cluster 2 was differentiated into fine sediment texture with a high OM content; however, a low amount of DO and high sulphide with high OM content was observed at these stations. In this case, low species abundance and diversity was observed at stations 3 and 4, where high $\mathrm{OM}$ and sulphide adversely affect benthic fauna (Jayaraj et al. 2007). This could also be evidenced from the 


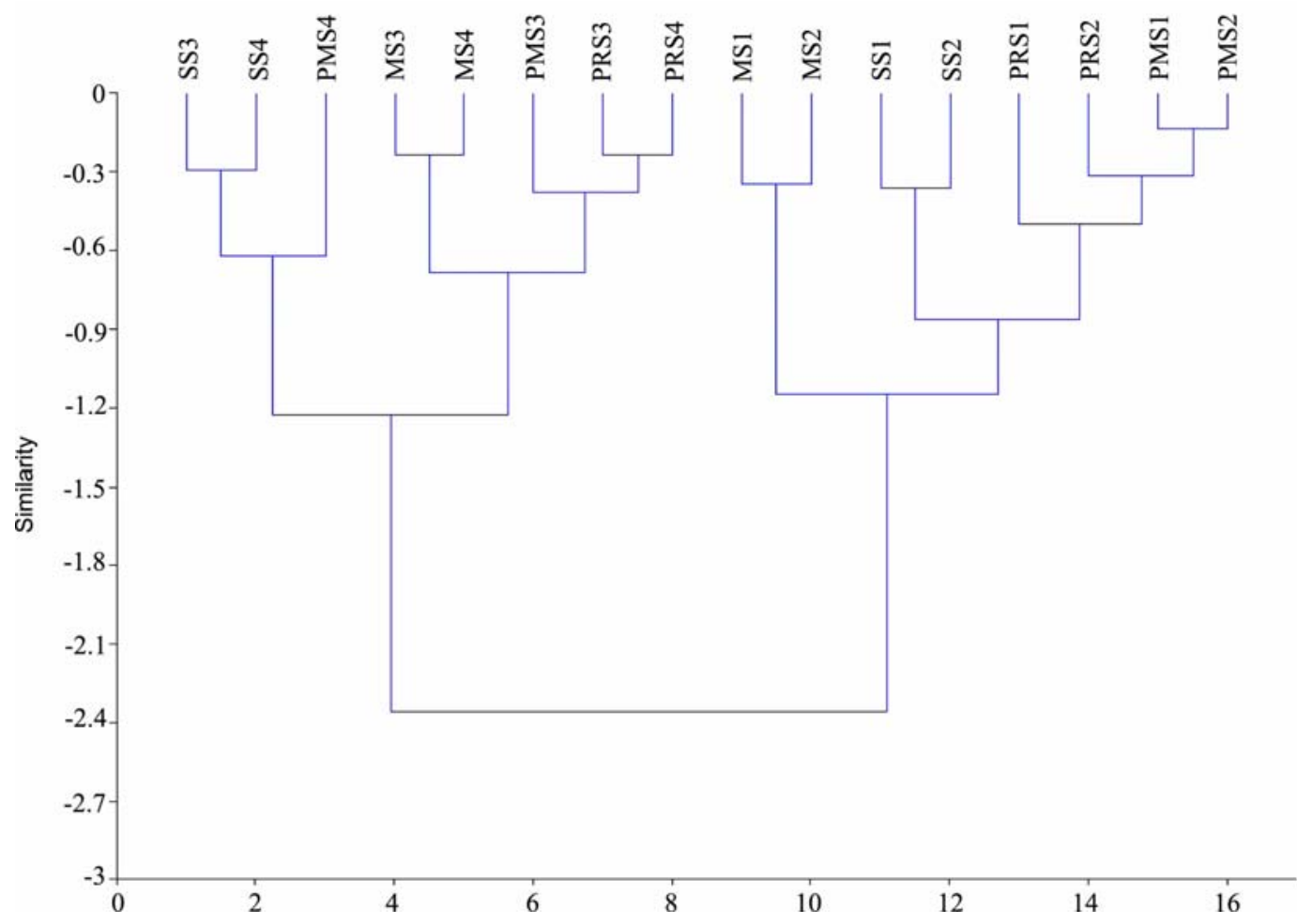

Fig. 6. Bray-Curtis similarity of molluscan abundance with physico-chemical parameters of water and sediment characteristics

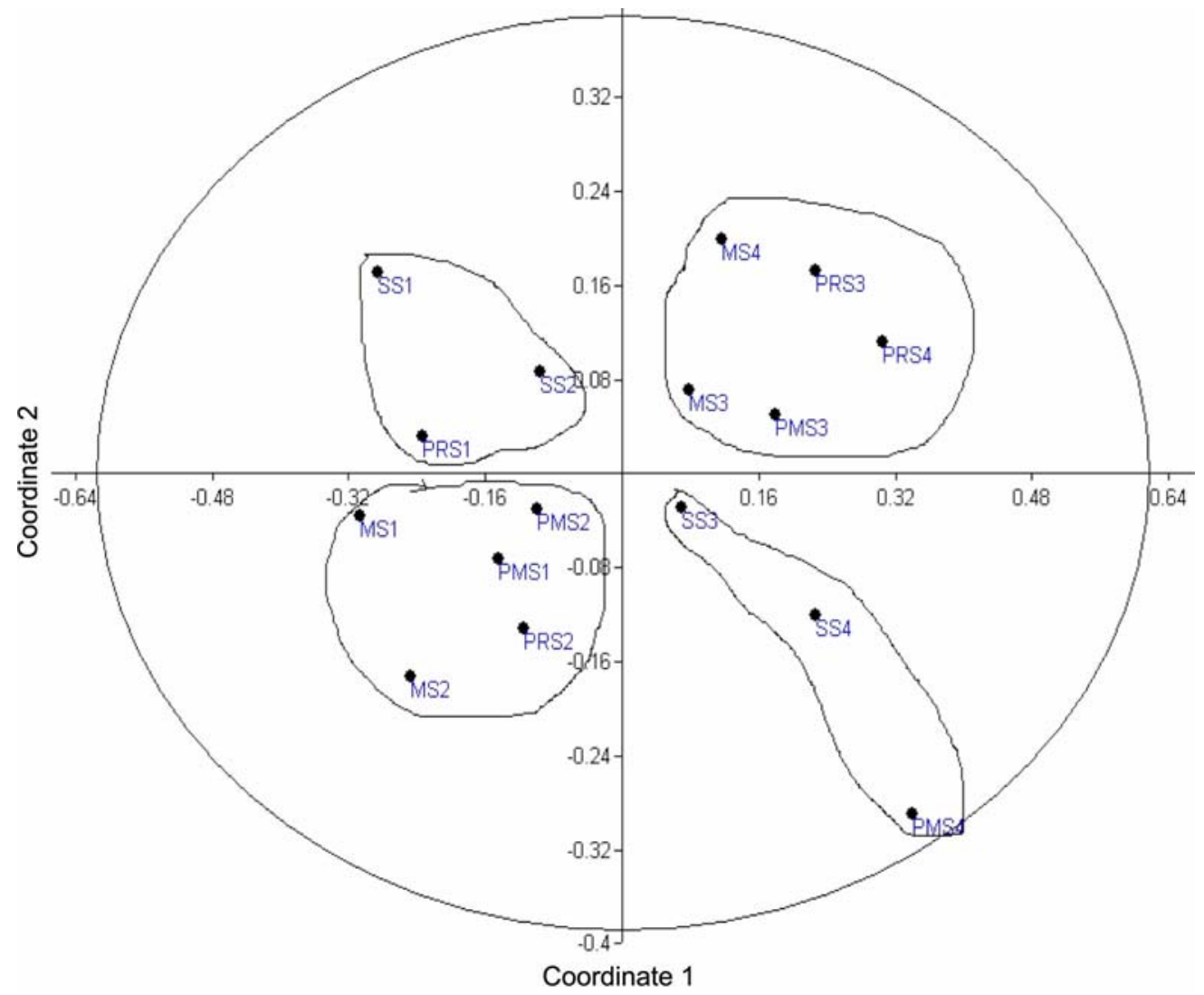

Fig. 7. Multidimensional scale plot indicating significant between molluscan abundance and physico-chemical parameters of water and sediment characteristics 
negative correlation of faunal groups obtained from the correlation analysis.

An MDS plot based on the average abundance of molluscan fauna and environmental parameters revealed four distinct groups with a $32 \%$ similarity in the study area (Fig. 7). Groups 1 and 2 were restricted to stations 1 and 2 in all the seasons and were characterised by the dominance of $C$. cingulata, Perna virdis. Groups 3 and 4 were observed at stations 3 and 4 and were dominated by $C$. nucleus, $M$. ceylonicus and S. minuta. Stations 3 and 4 remained separate as it did not cluster in any of the seasons with stations 1 and 2 , which confirms dendrogram.

Maximum diversity and richness recorded in this study during post monsoon might be due to stable environmental factors, such as DO and salinity, which play a vital role in faunal distribution. Relatively high species richness, evenness and diversity were observed in stations 1 and 2 and decreased towards station 3 and 4 . The low species richness recorded in this study during monsoon might be due to the freshwater inflow which induced low saline conditions, which in turn affected the distribution of benthos. Reason for the low richness and diversity in stations 3 and 4 may be due to the reduced temperature, oxygen and increased sulphide.

\section{Conclusions}

Results from the present study revealed that the diversity and distribution of molluses in the Pondicherry mangroves were controlled by a combination of factors and the effects that were organism dependent. The major factors were: sand, silt and clay, organic matter, dissolved oxygen, $\mathrm{pH}$, salinity and sulphide. Low benthic abundance and diversity was observed in the more polluted stations -3 and 4 - in the study area and they also revealed that a high deposition of $\mathrm{OM}$ and sulphide adversely affected the distribution of molluscs. High abundance, diversity and richness were recorded in stations 1 and 2 that were only slightly polluted. So it can be concluded that environmental parameters like $\mathrm{DO}, \mathrm{pH}$, sulphide, salinity $\mathrm{OM}$ and sediment texture have a great influence on the distribution, abundance and diversity of molluscs and refusal single factors by itself has controlling the entire.

\section{Acknowledgement}

Authors wish to thank the University Grants Commission, Government of India for their financial support and
Pondicherry University administration for providing infrastructure facilities.

\section{References}

Ashok Prabu V, Rajkumar M, Perumal P (2008) Seasonal variations in physico-chemical characteristics of Pichavaram mangroves, southeast coast of India. J Environ Biol 29:945-950

Balasubramanian R, Kannan L (2005) Physico chemical characteristics of the coral reef environs of the Gulf of Mannar Biosphere Reserve, India. Int J Ecol Environ Sci 31: 265-271

Bardarudeen T, Damodaran KT, Sajan K, Padmalal D (1996) Texture and geochemistry of the sediments of a tropical mangrove ecosystem, Southwest coast of India. Environ Geol 27:164-169

Bath KS, Kaur H, Dhillon SS (1999) Correlation of Molluscs with Physico-chemical factors at Harike Reservoir (Punjab). Indian J Environ Sci 3:159-163

Brendan P, Castilla KJC, Luis Prado, Paul York, Schwindt E, Bortolus A (2007) Spatial variation in molluscan assemblages from coralline turfs of Argentinean Patagonia. J Moll Stu 73:139-146

Danulat E, Muniz P, Garcia Alonso J, Yannicelli B (2002) First assessment of the highly contaminated harbour of Montevideo, Uruguay. Mar Pollut Bull 44:551-576

Eleftheriou A, Holme NA (1984) Macrofauna techniques. In: Holme NA, McIntyre AD (eds) Methods for the Study of Marine Benthos, IBP Handbook 16. Blackwell Scientific Publications, Oxford, UK, pp 140-216

El Wakeel SK, Riley JP (1957) The determination of organic carbon in marine muds. Cons Per Inte l'Explde Mer J 22:180183

Ellingsen KE (2002) Soft-sediment benthic biodiversity on the continental shelf in relation to environmental variability. Mar Ecol Prog Ser 232:15-27

Ellison AM (2008) Managing mangroves with benthic biodiversity in mind: moving beyond roving banditry. J Sea Res 59:2-15

Fenchel T (1970) Studies on the decomposition of organic detritus derived from the turtle grass Thalassia testudinum. Limnol Oceanogr 15: 14-20

Fernando A, Fernando OJ (2002) A field guide to the common invertebrates of the east coast of India, Annamalai Univerisity, India, $258 \mathrm{p}$

Field JG, Clarke KR, Warwick RM (1982) A practical strategy for analyzing multispecies distribution patterns. Mar Ecol Prog Ser 8:37-52

Garg RK, Rao RK, Saksena DN (2009) Correlation of molluscan diversity with physic-chemical characteristics of water of Ramsagar reservoir, India. Int J Biodivers Conserv 6:202-207

Gladstone W (2002) The potential value of indicator groups in the 
selection of marine reserves. Biol Conserv 104:211-220

Gleason HA (1992) On the relation between species and area. Ecology 3:156-162

Hemminga MA, Duarte CM (2000) Seagrass ecology. Cambridge University Press, Cambridge, 298 p

Ingole B, Sivadas S, Goltekar R, Clemente S, Nanajkar M, Sawant R (2006) Ecotoxicological effect of grounded MV river princess on the intertidal benthic organisms of Goa. Environ Int 32:284-289

Jayaraj KA, Jayalakshmi KV, Saraladevi K (2007) Influence of environmental properties on macrobenthos in the northwest Indian shelf. Environ Mon Ass 127:459-475

Jones CG, Lawton JH, Shachak M (1997) Positive and negative effects of organisms as physical ecosystem engineers. Ecology 78:1946-1957

Kathiresan K, Rajendran N, Palaniselavam V (2000) Growth of Rhizophora apiculata in degraded areas of Ariyankuppam estuary along Pondicherry coastline, southeast coast of India. Indian J Mar Sci 29:86-88

Krumbein WC, Petttijohn FJ (1983) Manual of sedimentary Petrography. Appleton Century- Crafts Inc, New York, 549 p

Manjappa H, Gowda G, Rajesh KM, Miridula (2003) Sediment characteristics of mangrove areas of brackishwater impoundments. Indian J Fish 50(3):349-354

Nordhaus I, Hadipudjana, FA, Janssen R, Pamungkas J (2009) Spatio-temporal variation of macrobenthic communities in the mangrove-fringed Segara Anakan lagoon, Indonesia, affected by anthropogenic activities. Reg Environ Change 9:291-313

Olive H, Lee K, Gray A, Williams (2002) Spatial distribution patterns of Littoraria species in Hong Kong mangroves. Hydrobiology 481:137-145

Parulekar AH, Dhargalkar VK, Singbal SYS (1980) Benthic studies in Goa estuaries. Annual cycle of Macrofaunal distribution, production and trophic relation. Indian J Mar Sci 9:189-20

Pielou EC (1966) The measurement of diversity in different types of biological collection. Theor Biol 13:131-144

Qasim SZ (1982) Oceanography of the northern Arabian Sea. Deep-Sea Res 29:1041-1068

Rajaram R, Srinivasan M, Rajasegar M (2005) Seasonal distribution of physico-chemical parameters in effluent discharge area of Uppanar estuary, Cuddalore, South-east coast of India. J Environ Biol 26:291-297

Rajkumar M, Perumal P, Ashok Prabu V, Vengadesh Perumal N, Thillai Rajasekar K (2009) Phytoplankton diversity in Pichavaram mangrove waters from south-east coast of India. J Environ Biol 30:489-498

Raut D, Ganesh T, Murty NVSS, Raman AV (2005) Macro benthos of Kakinada Bay in the Godavari delta, East coast of India: comparing decadal changes. Estuar Coast Shelf Sci 62:609-620

Sanders HL, Mangelsdorf PC, Hampson GR (1965) Salinity and faunal distribution in the Pocasset River, Massachusetts. Limnol Oceanogr 10:216-229

Sandilyan S, Thiyagesan K, Nagarajan R, Jayshree Vencatesan (2010) Salinity rise in Indian mangroves a looming danger for coastal biodiversity. Curr Sci 98(6):754-756

Saravanakumar A, Sesh Serebiah, Thivakaran GA, Rajkumar M (2007) Benthic Macrofaunal assemblage in the Arid Zone Mangroves of Gulf of Kachchh-Gujarat. J Ocean Univ China 6:303-309

Saravanan KR, Ilangovan K, Anisa Basheer Khan (2008) Floristic and macro faunal diversity of Pondicherry mangroves, South India. Tropic Ecol 49(1):91-94

Shannon CE, Weaver W (1949) The mathematical Theory of communication. University of Illinois Press, Urbana, $117 \mathrm{p}$

Strickland JDH, Parsons TR (1972) A practical handbook of seawater analysis. Bull Fish Res Board Canada 167:311

Wilhm JL, Dorris TC (1966) Species diversity of benthic macro invertebrates in a stream receiving domestic and oil refinery effluents. Am Mid Natural 76:427-449 